2019-01

\title{
Changes in the biochemical and nutrient composition of seafood due to ocean acidification and warming
}

\author{
Lemasson, A
}

http://hdl.handle.net/10026.1/12840

\subsection{6/j.marenvres.2018.11.006 \\ Marine Environmental Research \\ Elsevier}

All content in PEARL is protected by copyright law. Author manuscripts are made available in accordance with publisher policies. Please cite only the published version using the details provided on the item record or document. In the absence of an open licence (e.g. Creative Commons), permissions for further reuse of content should be sought from the publisher or author. 


\section{Accepted Manuscript}

Changes in the biochemical and nutrient composition of seafood due to ocean acidification and warming

A.J. Lemasson, J.M. Hall-Spencer, V. Kuri, A.M. Knights

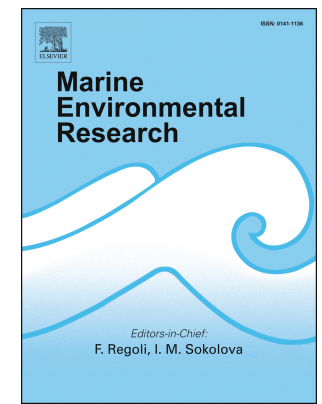

PII:

S0141-1136(18)30416-1

DOI: https://doi.org/10.1016/j.marenvres.2018.11.006

Reference: MERE 4643

To appear in: Marine Environmental Research

Received Date: 1 June 2018

Revised Date: 5 October 2018

Accepted Date: 15 November 2018

Please cite this article as: Lemasson, A.J., Hall-Spencer, J.M., Kuri, V., Knights, A.M., Changes in the biochemical and nutrient composition of seafood due to ocean acidification and warming, Marine Environmental Research (2018), doi: https://doi.org/10.1016/j.marenvres.2018.11.006.

This is a PDF file of an unedited manuscript that has been accepted for publication. As a service to our customers we are providing this early version of the manuscript. The manuscript will undergo copyediting, typesetting, and review of the resulting proof before it is published in its final form. Please note that during the production process errors may be discovered which could affect the content, and all legal disclaimers that apply to the journal pertain. 


\section{Changes in the biochemical and nutrient composition of seafood due to ocean}

\section{2 acidification and warming}

3

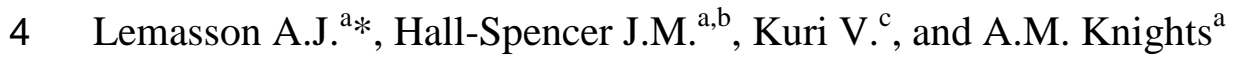

$6{ }^{a}$ Marine Biology and Ecology Research Centre, School of Biological and Marine Sciences,

7 University of Plymouth, Drake Circus, Plymouth, PL4 8AA. UK

$8{ }^{\mathrm{b}}$ Shimoda Marine Research Centre, University of Tsukuba, Shimoda City, Shizuoka, Japan

$9{ }^{\mathrm{c}}$ Food, Health and Nutrition, School of Biological and Marine Sciences, University of

10 Plymouth, Plymouth, Drake Circus, Plymouth, PL4 8AA. UK

11 *Corresponding Author: A.J. Lemasson (anaelle.lemasson@plymouth.ac.uk)

13 Abstract:

14 Ocean acidification and warming may threaten future seafood production, safety and quality by negatively impacting the fitness of marine species. Identifying changes in nutritional quality, as well as species most at risk, is crucial if societies are to secure food production. Here, changes in the biochemical composition and nutritional properties of the commercially valuable oysters, Magallana gigas and Ostrea edulis, were evaluated following a 12-week exposure to six ocean acidification and warming scenarios that were designed to reflect the temperature $\left(+3^{\circ} \mathrm{C}\right.$ above ambient) and atmospheric $p \mathrm{CO}_{2}$ conditions (increase of $350-$ 600ppm) predicted for the mid- to end-of-century. Results suggest that O. edulis, and especially M. gigas, are likely to become less nutritious (i.e. containing lower levels of protein, lipid, and carbohydrate), and have reduced caloric content under ocean acidification and warming. Important changes to essential mineral composition under ocean acidification and warming were evident in both species; enhanced accumulation of copper in M. gigas may 
26 be of concern regarding consumption safety. In light of these findings, the aquaculture

27 industry may wish to consider a shift in focus toward species that are most robust to climate

28 change and less prone to deterioration in quality, in order to secure future food provision and

29 socio-economic benefits of aquaculture.

30

31 Keywords: Oyster; living resources; biochemistry; food security; global change;

32 environmental stress; multi-stressors; Magallana gigas; Crassostrea gigas 
33

34

\section{Introduction}

Seafood is the source of $>15 \%$ of animal protein consumed globally, yet climate change is of increasing threat to the security of this resource (FAO, 2014: Golam et al., 2017; Rice and Garcia, 2011). This, as well as the continued burgeoning human population (Gerland et al., 2014; United Nations, 2015), especially in coastal areas (Firth et al., 2016), are placing increasing and arguably unsustainable demands on sources of animal protein, which are unlikely to be met by land farming (Campbell et al., 2017; Cooley et al., 2012; Delgado, 2003). Some argue the marine environment can make up the shortfall via a 'Blue Revolution'. But as overfishing, habitat destruction, and climate change are already causing decline in fish stocks in many areas (Macura et al., 2016; McCauley et al., 2015; Pauly et al., 1998), there is growing concern about the resilience of the marine environment to withstand increased anthropogenic pressure and provide sustainable food provision in the future (Knights et al., 2015; Porter et al., 2014; UNEP, 2010; Weatherdon et al., 2016).

Aquaculture is increasingly promoted as an alternative to land-based meat production and a solution for securing food provision in the future (Gentry et al., 2017; Naylor et al., 2000; Tacon \& Metian, 2013). The aquaculture industry is the fastest growing food sector, with production increasing nearly year-on-year since the 1950s (FAO, 2016), which has now surpassed that of capture fisheries. Molluscan aquaculture is increasingly important, with many molluscs strategically chosen due to their low production cost compared to that of other fish and shellfish due to no requirement for feed (Tacon \& Metian, 2013; Troell et al. 2014). In $2015, \sim 15 \%$ of the total aquaculture production volume was attributed to molluscan aquaculture (over 16 million tonnes; worth over US\$18billion) (FAO 2018). Additionally, mollusc aquaculture has been found as having the lowest environmental production impacts 
57 of all animal source food, and therefor may constitute a more sustainable source of protein

58 (Froehlich et al., 2018; Hilborn et al., 2018).

59

60 The increased prevalence of obesity in several regions of the world (Abarca-Gómez et al., 61 2017) is leading to greater public awareness and desire to consume a healthy and balanced 62 diet. A healthy diet should include sufficient proteins, amino acids, essentials fats such as long-chain omega-3 fatty acids, vitamins and minerals (FAO, 2016; Simopoulos, 2002). The proximate composition can be used as a measure of nutritional quality (see EFSA NDA Panel, 2014; Hart \& Fisher, 1971; Nielsen, 2006; Tate et al., 2017), dividing the food into fractions including moisture, ash, protein, lipids and minerals. Seafood contains high levels of these important components compared to other meats (reviewed in Tacon \& Metian, 2013) and is therefore viewed as highly nutritious, and key to human health and well-being (FAO/WHO, 2011; Lloret et al., 2016; Simopoulos, 2002). Oysters, in particular, are a popular and wellknown natural source of these nutrients (Asha et al., 2014; Cochet et al., 2015; Orban et al., 2004; Pogoda et al., 2013; Sprague et al., 2017).

In 2015, global oyster production exceeded 5.4 million tonnes, and was valued at $>$ US $\$ 4$ billion. In the UK, oysters are one of the major aquaculture species (Pinnegar et al., 2017) with $\sim 1600$ tonnes produced in 2015 , and worth more than US\$6.4 million. Yet there is increasing concern over the long-term future of shellfish production due to the effects of environmental stressors associated with rising atmospheric $\mathrm{CO}_{2}$ levels such as warming and marine heat waves, falling levels of seawater carbonate and oxygen plus rising sea levels and increased storminess (Branch et al., 2013; Cooley et al., 2015; Dupont et al., 2014; Ekstrom et al., 2015; Lemasson et al., 2017b). Ocean acidification and sea-surface warming are changing animal physiology and affecting the quality of seafood (Dupont et al., 2014; Tate et 
$a l ., 2017)$. In oysters, the effects of ocean acidification are already being detected (Lemasson

et al., 2017a), with several hatcheries experiencing declines in production, jeopardising

84

economic revenues and necessitating adaptive actions (Barton et al., 2015; Cooley et al., 2017). However, physiological effects of ocean acidification and warming in oysters appear species-specific (Lemasson et al., 2018).

To date, there has been limited consideration of potential changes in the quality of shellfish under warming and acidification. The few published studies have shown changes, such as reductions in protein and lipid content, and reductions in omega-3 fatty acids ( Ab Lah et al., 2018; Clements et al., 2018; Tate et al., 2017; Valles-Regino et al., 2015). A better understanding is needed if we are to shed light on the future of shellfish aquaculture. Here, using two economically and commercially important species of oysters, Magallana gigas - a non-native introduced species - and Ostrea edulis - a native species -, we tested if ocean acidification and warming conditions predicted under future climate scenarios has the potential to impact seafood nutritional quality. We also consider how condition indices - a widely used metric in aquaculture for evaluating health and value of bivalves because they are correlated with meat yield (Knights, 2012; Orban et al. 2002, 2006) - might change under ocean acidification and warming scenarios.

\section{Methods}

2.1 Organism collection and treatments

Collection of organisms, acclimation, treatments, and mesocosm set-up followed the protocol described in Lemasson et al. (2018). Following 14 days of acclimation to laboratory conditions $\left(16^{\circ} \mathrm{C}\right.$, salinity $33, \sim 400$ ppm $p \mathrm{CO}_{2}, 12: 12$ dark:light cycle, fed ad libitum with a 
mixed algal diet (Shellfish Diet, 1800; Reed Mariculture)), each oyster was placed in its own

$3 \mathrm{~L}$ experimental tank and exposed for 12 weeks to three $p \mathrm{CO}_{2}$ concentrations (ambient $\sim 400$

ppm, intermediate $\sim 750 \mathrm{ppm}$, elevated $\sim 1000 \mathrm{ppm}$ ), and two temperatures (control $16.8{ }^{\circ} \mathrm{C}$,

110 elevated $20{ }^{\circ} \mathrm{C}$ ) in an orthogonal experimental design (M. gigas $\mathrm{n}=4$; O. edulis $\mathrm{n}=8$

111 individuals per treatment). This design aimed to simulate current and future ocean

112 acidification and warming scenarios, using scenarios in line with conditions predicted by the

113 IPCC (IPCC, 2013) and for the UK for mid- to end-century (see also Lemasson et al., 2018).

114 Throughout the study, oysters were fed ad libitum with a mixed algal diet (Shellfish Diet,

115 1800; Reed Mariculture).

116

117 Temperature, salinity, and $\mathrm{pH}$ were measured daily in all replicate tanks. Salinity was measured using a handheld refractometer (D\&D The Aquarium Solution Ltd, Ilford, UK) and temperature measured using a digital thermometer (TL; Fisher Scientific, Loughborough, UK). pH was measured using a microelectrode (InLab® Expert Pro-ISM; Mettler- Toledo Ltd, Beaumont Leys, UK) coupled to a $\mathrm{pH}$ meter (S400 SevenExcellence ${ }^{\mathrm{TM}}$; Mettler-Toledo Ltd, Beaumont Leys, UK), following calibration with NIST traceable buffers. $\mathrm{pH}$ in the header tanks was also monitored (data not shown). Total Alkalinity (AT) was measured once a week in each of the replicate tanks. $125 \mathrm{~mL}$ water samples were transferred to borosilicate bottle with Teflon caps and poisoned with $30 \mu \mathrm{L}$ of saturated $\mathrm{HgCl}_{2}$ solution $(0.02 \%$ sample volume) before being kept in the dark until measurement by automatic Gran titration

127 (Titralab AT1000 (C) Hach Company). Partial pressure of carbon dioxide $\left(p \mathrm{CO}_{2}\right)$ and saturation states of calcite and aragonite ( $\Omega$ calcite and $\Omega$ aragonite), were calculated at the end of the experiment using $\mathrm{CO}_{2}$ SYS (Pierrot et al., 2006), employing constants from Mehrbach et al. (1973) refitted to the NBS pH scale by Dickson and Millero (1987) and the $\mathrm{KSO}_{4}$ dissociation constant from Dickson (1990). 
133 Table 1: Seawater chemistry for Magallana gigas and Ostrea edulis in each treatment. Data 134 shown are means $( \pm \mathrm{SD})$ values. $\mathrm{T}=$ Temperature in ${ }^{\circ} \mathrm{C}$. ppm $=$ parts per million. $\Omega_{\mathrm{Ca}}=$ 135 saturation state of calcite. $\Omega_{\mathrm{Ar}}=$ saturation state of aragonite. $\mathrm{A}_{\mathrm{T}}=$ Total alkalinity in $\mathrm{mmol} / \mathrm{kg}$ 136 seawater.

\begin{tabular}{|c|c|c|c|c|c|c|c|}
\hline \multirow{2}{*}{$\begin{array}{c}\text { Treatment } \\
\left(p \mathrm{CO}_{2}+\text { Temperature }\right)\end{array}$} & \multicolumn{4}{|c|}{ Measured } & \multicolumn{3}{|c|}{ Calculated } \\
\hline & $\mathrm{pH}$ & $\mathrm{T}$ & $\mathrm{A}_{\mathrm{T}}$ & S & $p \mathrm{CO}_{2}$ & $\Omega A r$ & $\Omega \mathrm{C}_{\mathrm{a}}$ \\
\hline Ambient + Control & $7.79 \pm 0.10$ & $16.9 \pm 0.2$ & $2.13 \pm 0.32$ & $33.9 \pm 1.1$ & $597.2 \pm 146.1$ & $1.70 \pm 0.32$ & $2.64 \pm 0.50$ \\
\hline $750 \mathrm{ppm}+$ Control & $7.67 \pm 0.12$ & $16.9 \pm 0.2$ & $2.13 \pm 0.33$ & $33.9 \pm 1.2$ & $816.9 \pm 296.4$ & $1.4 \pm 0.36$ & $2.10 \pm 0.55$ \\
\hline 1000 ppm + Control & $7.55 \pm 0.10$ & $16.8 \pm 0.2$ & $2.13 \pm .032$ & $33.9 \pm 1.2$ & $1174.6 \pm 420.9$ & $0.99 \pm 0.22$ & $1.53 \pm 0.34$ \\
\hline Ambient + Elevated & $7.84 \pm 0.10$ & $20.4 \pm 0.3$ & $2.32 \pm 0.29$ & $34.3 \pm 1.2$ & $669.7 \pm 155.9$ & $2.02 \pm 0.31$ & $3.11 \pm 0.47$ \\
\hline 750 ppm + Elevated & $7.70 \pm 0.11$ & $20.6 \pm 0.4$ & $2.33 \pm 0.29$ & $34.2 \pm 1.1$ & $945.1 \pm 275.7$ & $1.60 \pm 0.34$ & $2.46 \pm 0.52$ \\
\hline 1000 ppm + Elevated & $7.56 \pm 0.10$ & $20.2 \pm 0.3$ & $2.34 \pm 0.31$ & $34.3 \pm 1.2$ & $1376.8 \pm 280.8$ & $1.14 \pm 0.17$ & $1.76 \pm 0.26$ \\
\hline Ambient + Control & $8.00 \pm 0.08$ & $16.5 \pm 0.3$ & $3.04 \pm 0.18$ & $34.2 \pm 0.8$ & $481.4 \pm 90.9$ & $3.70 \pm 0.65$ & $5.75 \pm 1.01$ \\
\hline $750 \mathrm{ppm}+$ Control & $7.84 \pm 0.08$ & $16.6 \pm 0.2$ & $3.04 \pm 0.19$ & $34.2 \pm 0.8$ & $760.1 \pm 178.2$ & $2.68 \pm 0.51$ & $4.17 \pm 0.80$ \\
\hline 1000 ppm + Control & $7.72 \pm 0.16$ & $16.6 \pm 0.2$ & $3.00 \pm 0.16$ & $34.3 \pm 0.7$ & $1053.6 \pm 223.3$ & $2.15 \pm 1.20$ & $3.34 \pm 1.87$ \\
\hline Ambient + Elevated & $8.00 \pm 0.08$ & $19.8 \pm 0.3$ & $2.86 \pm 0.15$ & $34.4 \pm 0.9$ & $467.9 \pm 78.4$ & $3.80 \pm 0.65$ & $5.85 \pm 1.01$ \\
\hline $750 \mathrm{ppm}+$ Elevated & $7.90 \pm 0.07$ & $20.2 \pm 0.5$ & $2.87 \pm 0.15$ & $34.4 \pm 09$ & $694.7 \pm 135.4$ & $2.94 \pm 0.47$ & $4.52 \pm 0.72$ \\
\hline 1000 ppm + Elevated & $7.70 \pm 0.09$ & $19.8 \pm 0.3$ & $2.6 \pm 0.22$ & $34.4 \pm 0.9$ & $1165.0 \pm 226.8$ & $2.01 \pm 0.47$ & $3.10 \pm 0.73$ \\
\hline
\end{tabular}

1382.2 Condition index, proximate composition, and energy content

139 After 12 weeks exposure, oysters were manually shucked and their wet tissue mass (g) was

140 recorded on an electronic balance (Mettler AE240), before being oven-dried at $105^{\circ} \mathrm{C}$ for 24

141 hours until constant mass was achieved.

142

143 The Condition Index (CI) of each oyster was calculated following the method recommended

144 by Lucas and Beninger (1985) as follows:

$$
C I=(\text { dry meat weight } / \text { dry shell weight }) \times 100
$$


146 Moisture percentage of the meat was calculated for each individual oyster according to the

147 following formula:

$$
\text { Moisture }(\%)=((\text { Total weight }- \text { Dry weight }) / \text { Total weight }) \times 100
$$

148

149 For each species, following estimation of Condition Index and moisture content for all 150 individuals, the dried meat samples were then pooled by treatment to provide sufficient tissue material for proximate composition and energy content analyses. Pooled samples were homogenised, then ground into a fine powder using a coffee grinder. Complete or partial pooling of specimens from the same treatment or sampling site for biochemical analysis has been reported in several studies (Fernandez et al., 2015; Marin et al., 2003; Soto-Jiménez et al., 2001). While not allowing individual comparisons, this approach provides nutritional information at the population level. The following assays were performed in triplicate.

Ash content (a measure of the total amount of minerals present within a food) was determined using 500mg of dried tissue samples and an adaptation of the Association of

160 Official Agricultural Chemists official method (AOAC, 1995). Lipid content was determined by continuous extraction of fat from $2 \mathrm{~g}$ material using petroleum ether as a solvent following the Soxhlet method (Luque de Castro \& García-Ayuso, 1998; Manirakiza et al., 2001) in a Soxtherm Rapid Extraction Unit (C. Gerhardt GmbH \& Co. KG). Total protein content was

164 determined using the Kjeldahl method (Kjeldahl, 1883) on 150 mg samples with a Gerhardt 165 Kjeldatherm digestion block, a Gerhardt Turbosog scrubber unit and a Gerhardt Vapodest 50s 166 distillation unit (Gerhardt Laboratory Instruments, Bonn, Germany). Glycogen content was determined indirectly by calculating carbohydrate content using the above results for moisture, ash, lipid, and protein content following Maclean et al. (2003) as follows:

$$
\text { Carbohydrates }(\%)=100-(\% \mathrm{M}+\% \mathrm{~A}+\% \mathrm{~L}+\% \mathrm{P})
$$


169

170

171

172

173 Caloric (energy) content was measured as gross energy content $\left(\mathrm{kJ}^{\mathrm{g}} \mathrm{g}^{-1}\right)$ by bomb calorimetry

Where:

$\mathrm{C}=$ carbohydrate, $\mathrm{M}=$ moisture, $\mathrm{A}=\mathrm{ash}, \mathrm{L}=$ lipid, and $\mathrm{P}=$ protein. All values used were as percentage of total weight.

using an isoperibol oxygen bomb calorimeter (Parr Instrument Company, Moline, Illinois, USA) on $\sim 1 \mathrm{~g}$ of material per sample.

176

177 was used to verify the digestion procedure as reported elsewhere (Rossbach et al., 2017).

\subsection{Macro and micro-minerals}

Macro-mineral (calcium $[\mathrm{Ca}]$, potassium $[\mathrm{K}]$, magnesium $[\mathrm{Mg}]$, sodium $[\mathrm{Na}]$ ) and micromineral (copper $[\mathrm{Cu}]$, iron $[\mathrm{Fe}]$, zinc $[\mathrm{Zn}]$ ) content was determined using an Inductively Coupled Plasma Optical Emission Spectrometer (ICP-OES; iCAP 7000series Thermo Scientific) following standard protocols as reported elsewhere (Rider et al., 2010). The content of the micro-mineral selenium [Se] was determined using an Inductively Coupled Plasma Mass Spectrometer (ICP-MS; Xseries2, Thermo Scientific) following standard protocols. Mineral composition was determined on $\sim 100-150 \mathrm{mg}$ of material per sample. Before use, both ICP-OES and ICP-MS were calibrated using mixed, matrix-matched standards (0-100 $\left.\mu \mathrm{g} . \mathrm{L}^{-1}\right)$ prepared from certified Aristar plasma emission grade solutions. Quality control was assured by carrying out accuracy checks using a known standard or blank every 10 samples during the analysis. Also, 2\% internal iridium and indium standards (P/N/4400-013 CPI, Quality control standard 26) were added to each sample. DORM-3 (dogfish certified reference material - CRM) from National Research Centre Canada (NRCC)

\subsection{Statistical analyses}


193 The logistical constraints of the experimental infrastructure meant oyster species had to be 194 tested sequentially. There were natural variations in the chemistry of the seawater used 195 between experiments due to natural seasonal fluctuations in seawater properties combined 196 with differences in atmospheric partial pressure (barometric pressure). These fluctuations in $197 p \mathrm{CO}_{2}$ also led to fluctuations in $\mathrm{CO}_{2}$ adsorbed by the seawater. The resulting $p \mathrm{CO}_{2}$, and $\mathrm{pH}$, 198 conditions were therefore different between experiments, but also within experiments were 199 different from the expected levels of $\sim 400 \mathrm{ppm}, \sim 750 \mathrm{ppm}$ and $\sim 1000 \mathrm{ppm}$. Nevertheless, the effect size (magnitude of difference in $\mathrm{pCO}_{2}$ and $\mathrm{pH}$ between treatments within experiments) were comparable. These constraints prevented a formal comparison of the two species in a 202 factorial design, so these were analysed separately. Analyses were performed using R 203 Version 3.2.5 (R Core Development Team, 2018) using the base, MASS, stat and vegan packages. $\mathrm{p}<0.05$ was used as statistical threshold.

Condition Index and Moisture content

208 Condition index and moisture data (obtained before pooling of the samples) were tested for homogeneity of variances using Levene's test (car package). Tests for differences in condition index and moisture content between treatments were done using 2-factor ANOVA with 'temperature' and ' $p \mathrm{CO}_{2}$ ' as fixed factors.

212

213 Proximate composition, energy content, and mineral composition

214 As oyster tissues were pooled in order to provide sufficient material to perform these analyses, 215 there were no 'true replicates' (sensu Hurlbert, 1984). Triplicate measures of protein, lipid, 216 ash, calorimetry, and mineral analysis were performed to determine within sample 217 variability.Data were pooled, and averages used for statistical analysis to avoid Type I error. 
218 The pooled samples used were therefore homogenised samples of multiple individuals $(M$.

219 gigas $\mathrm{n}=4$; O. edulis $\mathrm{n}=8$ ), and in effect the single values associated with each assay are

220 means without the variances. Analyses were thus performed on these single values.

221

222 Calorimetry data were analysed using a 2-way ANOVA with 'temperature' and ' $p \mathrm{CO}_{2}$ ' as

223 fixed factors ( $\mathrm{n}=3$ per Temperature level; $\mathrm{n}=2$ per $p \mathrm{CO}_{2}$ level). Due to this experimental 224 design, interactions between the two factors could not be assessed.

225

226

To compare proximate and mineral compositions across species, temperature and $p \mathrm{CO}_{2}$, 227 nonmetric multidimensional scaling (nMDS) coupled with Permutational Multivariate 228 Analysis of Variance (PERMANOVA, Anderson, 2001) was used to evaluate the 229 significance of observed patterns (based on Euclidian distance and 1000 permutations of the data) and test hypotheses related to changes in composition due to experimental treatment.

232 For tests using ANOVA, when significant differences were present, post-hoc Tukey tests 233 were performed to assess differences between treatment levels.

\section{Results}

3.1 Condition Index and Moisture

237 Temperature, but not $p \mathrm{CO}_{2}$, had a significant effect on the condition index of $M$. gigas $\left(F_{1,12}\right.$ $238=12.298 ; \mathrm{p}<0.01$ ), with condition index negatively impacted by elevated temperature (Figure 1a). Mean condition index decreased $35 \%$ with increased temperature, from $\sim 3.2( \pm 0.3)$ at ambient temperature to $\sim 2.1( \pm 0.20)$ at elevated temperature. While marginally not

241 significant $\left(F_{2,18}=2.97 ; \mathrm{p}=0.07\right)$, there were clear differences in condition indexbetween $M$.

242 gigas cultured under different temperature and $p \mathrm{CO}_{2}$ regimes, with a trend toward increasing 
243 condition indexwith increasing $\mathrm{pCO}_{2}$ at the control temperature, and decreasing condition

244 indexwith increasing $p \mathrm{CO}_{2}$ at elevated temperature (Figure 1a). The condition indexof

245 O. edulis was unaffected by any of the treatments. Moisture - the principal contributor to 246 oyster flesh - was also unaffected by temperature or $p \mathrm{CO}_{2}$ treatment and ranged between 70-

$24780 \%$ for both species (Table 2; Figure 1b).

a)

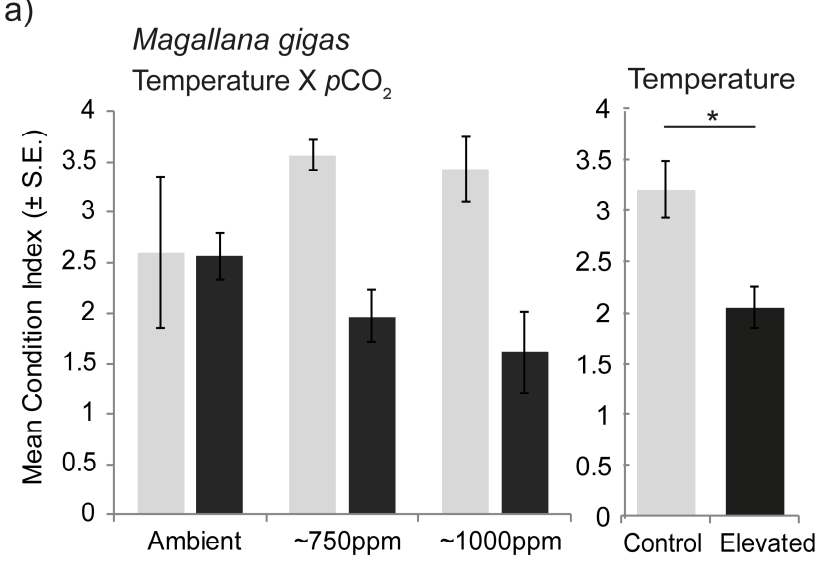

Ostrea edulis

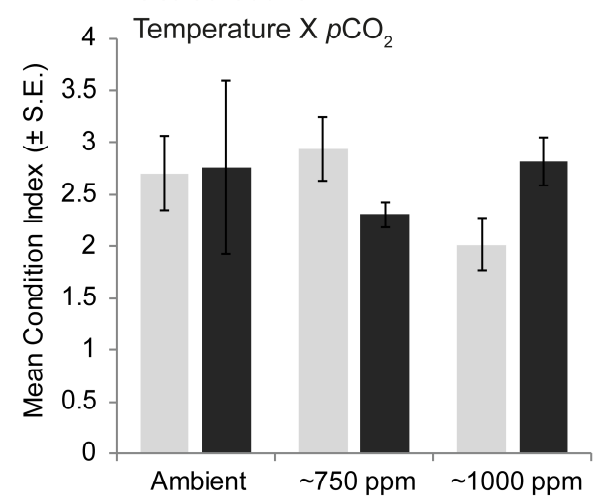

b)

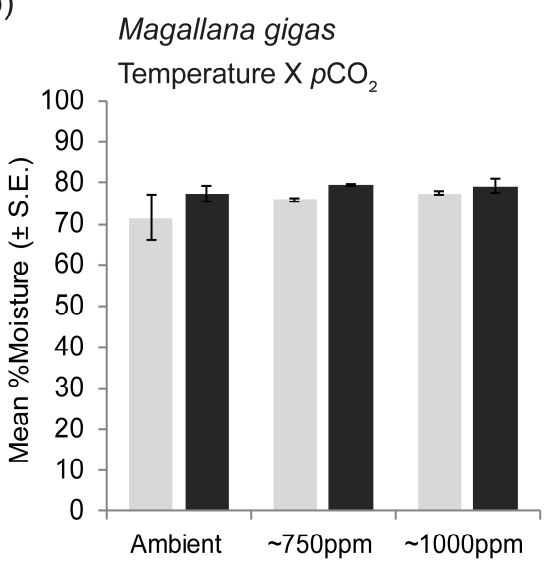

Ostrea edulis

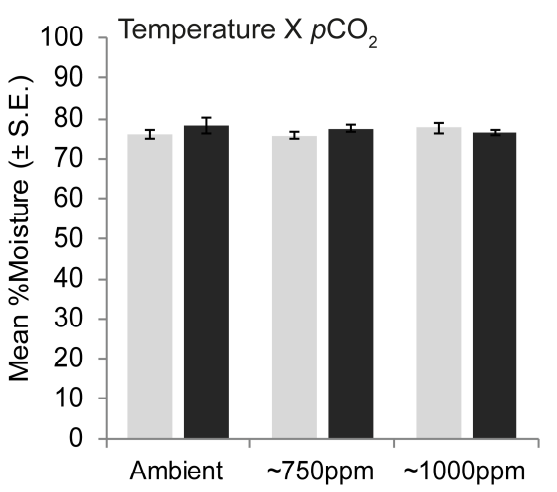

Figure 1 Difference in a) Condition Index and b) moisture content (as \% of total weight), of

251 Magallana gigas and Ostrea edulis across temperature and $p \mathrm{CO}_{2}$ treatments. ppm= part per 252 million; s.e. $=$ standard error. Grey $=$ control temperature. Black= elevated temperature. $*$ 253 indicates significant difference. 
256 There were significant differences in proximate composition with temperature and $p \mathrm{CO}_{2}$ for

257 both species (Magallana gigas: perm $\mathrm{F}_{2,24}=75.41 ; \mathrm{p}<0.001 ;$ Ostrea edulis: perm $\mathrm{F}_{2,24}=14.37$;

$258 \mathrm{p}<0.001)$ (Table 2, Figures $2 \& 3 \mathrm{a}-\mathrm{d}$ ). For all treatments, after moisture, protein was the 259 second largest component in both $M$. gigas and $O$. edulis under ambient $p \mathrm{CO}_{2}$ and control 260 temperature, representing $16.6 \%$ and $9.9 \%$ of the total composition, respectively (Table 2; 261 Figure 2). Ostrea edulis was characterised by higher carbohydrates (10.5g per $100 \mathrm{~g})$ than $M$. 262 gigas (4.5g per 100g), but M. gigas had higher percentages of proteins and lipids (Table 2,). 263 Temperature (Figure 3a-b) and $\mathrm{pCO}_{2}$ (Figure 3c-d) both led to clear dissimilarity in 264 proximate composition between species, with greater changes apparent in M. gigas, largely 265 driven by reductions in proteins and lipids (Table 2, Figure 2) from 16.6g to $11.8 \mathrm{~g}$ and from $2664.8 \mathrm{~g}$ to $1.4 \mathrm{~g}$, respectively. The treatments also appeared to a lesser degree to negatively 267 impact the carbohydrate proportion in M. gigas, which dropped from $4.9 \mathrm{~g}$ to $3.3 \mathrm{~g}$ (Table 2;

268 Figure 2). There were significant differences in proximate composition between all $p \mathrm{CO}_{2}$ 269 treatments in M. gigas, but in O. edulis, there was no difference between oysters cultured in 270400 and $1000 \mathrm{ppm}$, whereas those cultured in intermediate $p \mathrm{CO}_{2}(750 \mathrm{ppm})$ were significantly 271 different (Figure 3c). This was particularly evident in O. edulis for the lipid proportions, 272 which were reduced from $1.3 \mathrm{~g}$ to $0.9 \mathrm{~g}$ at elevated temperature and intermediate $p \mathrm{CO}_{2}(\sim 750$ 273 ppm) (Table 2; Figure 2). 
275 Table 2: Proximate composition of Magallana gigas and Ostrea edulis under six ocean 276 acidification and warming scenarios. Moisture represents the remaining component, adding 277 up to $100 \mathrm{~g}$. In g per $100 \mathrm{~g}$ sample (wet weight).

278

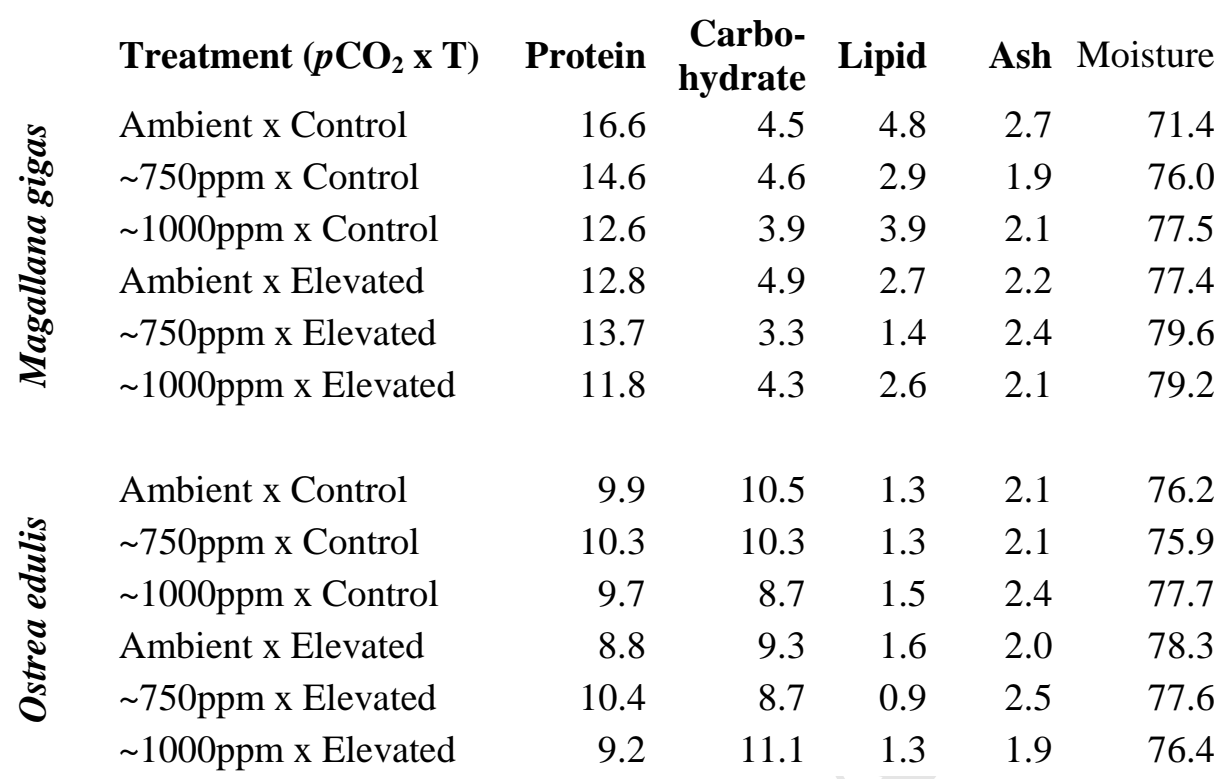


a) Magallana gigas
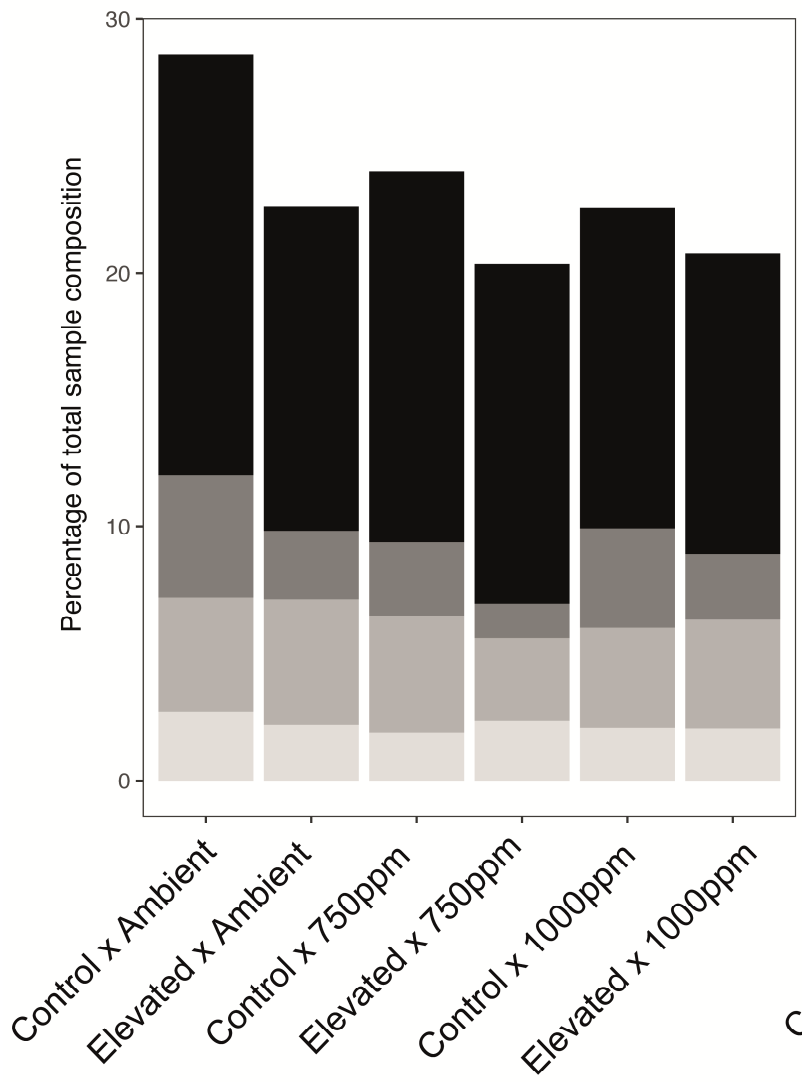

Ash

\section{b) Ostrea edulis}

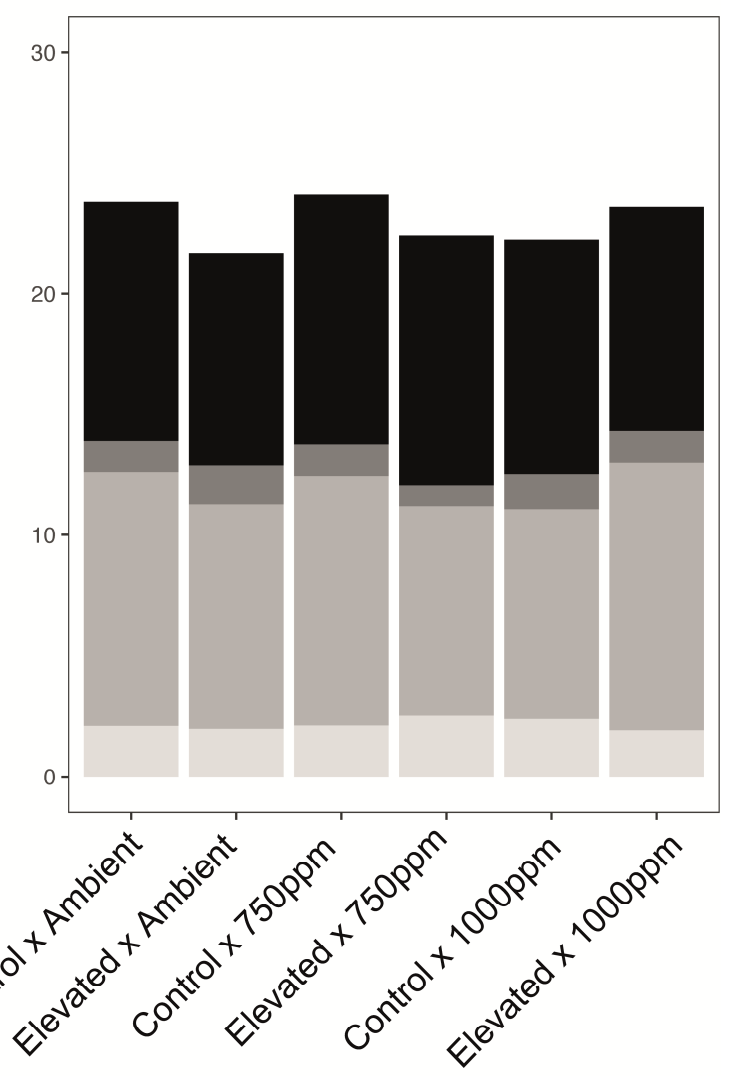

Lipids

Proteins

282 Figure 2: Relative composition of proximate components present in a) Magallana gigas and

283 b) Ostrea edulis across temperature and $p \mathrm{CO}_{2}$ treatments. The values for each treatment 284 represent the means of the three procedural replicates of the pooled samples. ppm= part per 285 million. 

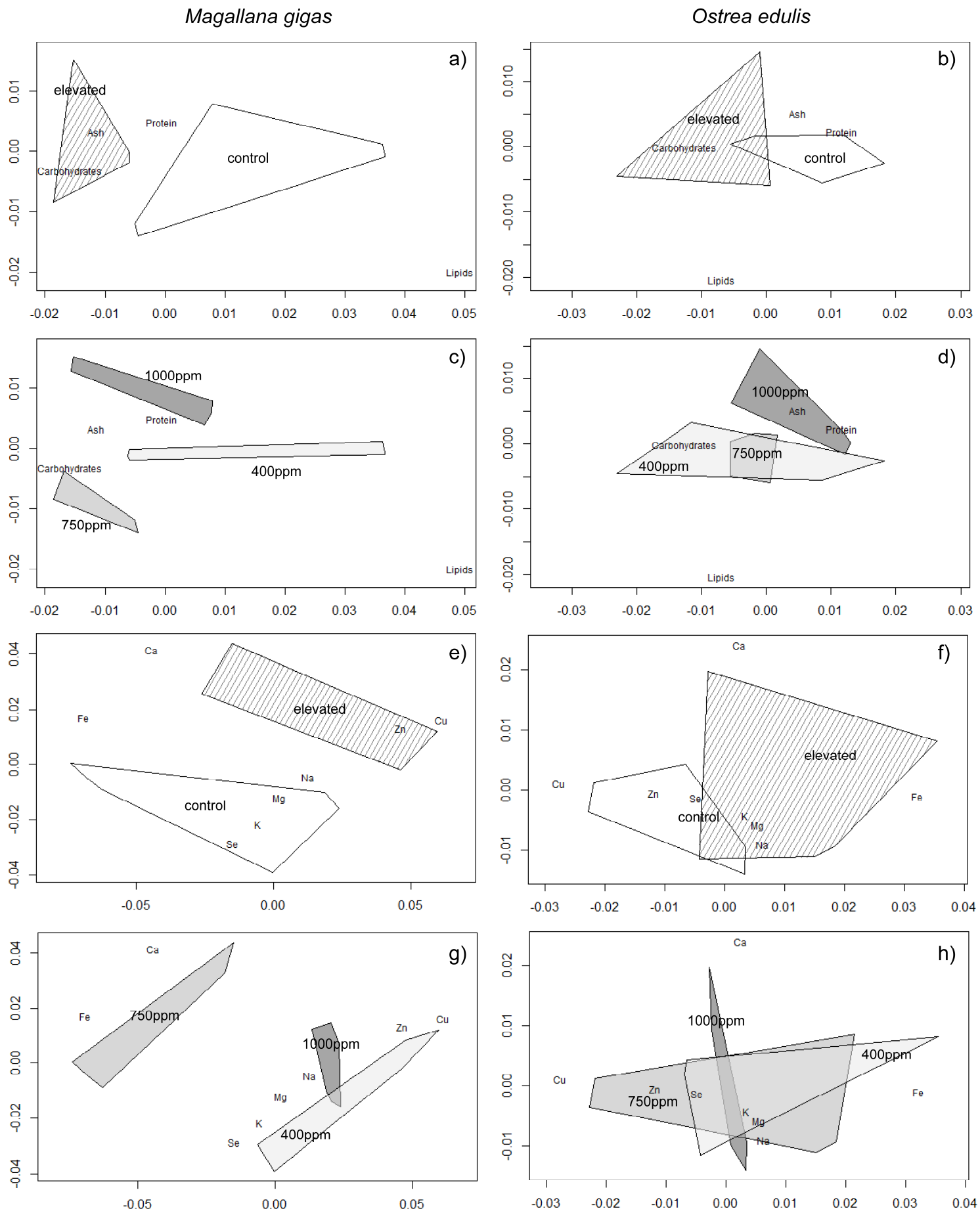

288 Figure 3: nMDS plots of proximate (a-d) and mineral compositions (e-h) of Magallana 289 gigas (left column) and Ostrea edulis (right column). Dispersion of points within temperature 290 (plots a, b, e, f) and $p \mathrm{CO}_{2}$ (plots $\mathrm{c}, \mathrm{d}, \mathrm{g}, \mathrm{h}$ ) treatments are illustrated using cluster hulls plotted 291 using the R package ' $g$ gplot2'. Centroids of each proximate composition and mineral components are shown. 2D stress for all plots $<0.08$. 


\subsection{Energy content}

295

There was a $13 \%$ reduction in the caloric content of $M$. gigas with temperature and $p \mathrm{CO}_{2}$ from $20.97 \mathrm{~kJ} / \mathrm{gDW}$ at control temperature and ambient $p \mathrm{CO}_{2}$ to $18.41 \mathrm{~kJ} / \mathrm{gDW}$ at elevated temperature and intermediate $p \mathrm{CO}_{2}(\sim 750 \mathrm{ppm})$ (Figure 4). The energetic value of $O$. edulis did not change $(17.63 \mathrm{~kJ} / \mathrm{gDW})$ with treatment (Figure 4).

299

300
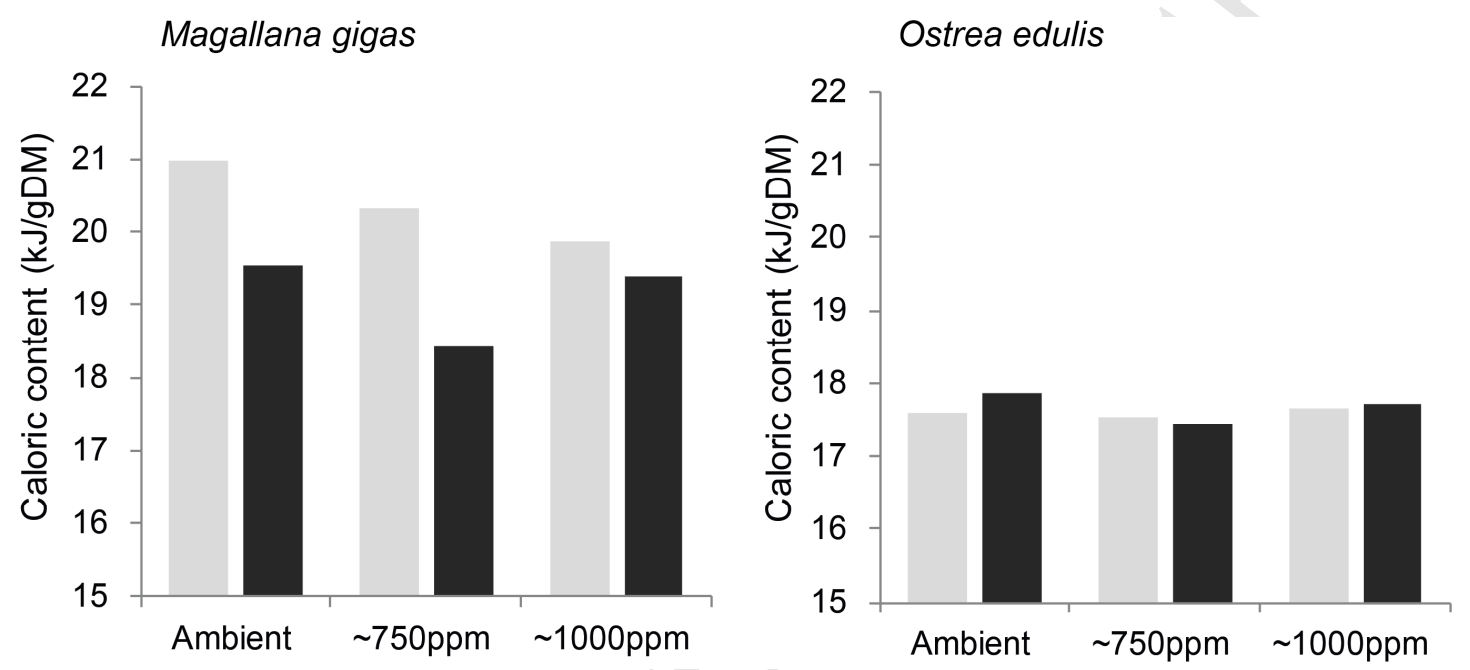

301

Figure 4: Variations in the caloric content of oysters across temperature and $p \mathrm{CO}_{2}$ treatments 302 for Magallana gigas (left) and Ostrea edulis (right). ppm= part per million; Light grey = control temperature. Dark grey= elevated temperature. The value for each treatment 304 represents the mean of the three procedural replicates of the pooled samples, therefore no 305 error bars were obtained. Values are per kg of oyster dry matter (DM).

\subsection{Trace elements}

308 There were significant differences in trace elements composition with, temperature and $p \mathrm{CO}_{2}$ levels for both species (Magallana gigas: perm $\mathrm{F}_{2,24}=166.75 ; \mathrm{p}<0.001 ;$ Ostrea edulis: perm

$310 \quad \mathrm{~F}_{2,24}=16.27 ; \mathrm{p}<0.001$ ) (Table 3, Figure 3e-h). Magallana gigas was characterised by higher

$311 \mathrm{Se}, \mathrm{Fe}, \mathrm{K}, \mathrm{Mg}$, and $\mathrm{Na}$ content than O. edulis (Table 3, Figure 3e-h), but O. edulis displayed

312 higher $\mathrm{Zn}$ levels. Temperature led to clear dissimilarity in the mineral composition of each 
313 oyster species, with greater change apparent in $M$. gigas (Figure 3e-fa). $p \mathrm{CO}_{2}$ also had

314 notable effects, but only on $M$. gigas (Table 3, Figure 3g-h). Overall, the mineral composition

315 of M. gigas was clearly affected by the treatments (Table 3), with notable increases in $\mathrm{Cu}$ and

316 Zn content, and decreases in Fe and Se contents.

317

318 Table 3: Mineral composition of Magallana gigas and Ostrea edulis under six ocean 319 acidification and warming scenarios. $\mathrm{T}=$ temperature. $\mathrm{ppm}=$ part per million $\mathrm{Ca}=$ calcium;

$320 \mathrm{Cu}=$ copper; $\mathrm{Fe}=\mathrm{Iron} ; \mathrm{K}=$ potassium; $\mathrm{Mg}=$ magnesium; $\mathrm{Na}=$ sodium; $\mathrm{Zn}=\mathrm{zinc}$; $\mathrm{Se}=$ selenium.

321 All values are in $\mathrm{mg} \cdot \mathrm{kg}^{-1}$, except Se which is in $\mu \mathrm{g} \cdot \mathrm{kg}^{-1}$.

322

\begin{tabular}{|c|c|c|c|c|c|c|c|c|}
\hline Treatment $\left(p \mathrm{CO}_{2} \times \mathrm{T}\right)$ & $\mathbf{C a}$ & $\mathbf{C u}$ & $\mathbf{F e}$ & $\mathbf{K}$ & Mg & $\mathbf{N a}$ & Zn & Se \\
\hline Ambient x Control & 1250.0 & 64.7 & 205.5 & 322.1 & 847.1 & 4626.3 & 450.3 & 537.1 \\
\hline 750ppm x Control & 492.8 & 60.0 & 35.7 & 268.1 & 553.5 & 3101.7 & 404.9 & 313.1 \\
\hline 1000ppm x Control & 618.1 & 149.0 & 54.0 & 270.2 & 676.7 & 3811.5 & 749.2 & 459.7 \\
\hline Ambient x Elevated & 1409.6 & 92.5 & 74.7 & 219.2 & 509.6 & 3111.3 & 566.8 & 248.8 \\
\hline 750ppm x Elevated & 544.5 & 202.0 & 57.7 & 260.4 & 793.6 & 5476.6 & 1063.2 & 309.4 \\
\hline 1000ppm x Elevated & 719.1 & 143.5 & 69.4 & 214.2 & 609.5 & 3969.1 & 798.3 & 314.0 \\
\hline Ambient $x$ Control & 1567.2 & 196.2 & 48.4 & 277.4 & 546.0 & 3747.0 & 1077.3 & 263.6 \\
\hline 750ppm x Control & 1535.5 & 127.1 & 39.3 & 253.3 & 496.8 & 3390.0 & 862.9 & 232.8 \\
\hline 1000ppm x Control & 1353.5 & 103.0 & 42.0 & 270.7 & 636.7 & 4571.7 & 940.0 & 252.1 \\
\hline Ambient x Elevated & 1267.3 & 87.6 & 55.9 & 257.4 & 501.3 & 3503.5 & 623.8 & 192.0 \\
\hline 750ppm x Elevated & 1560.6 & 111.1 & 64.8 & 258.8 & 539.5 & 3842.1 & 879.7 & 256.1 \\
\hline 1000ppm x Elevated & 2142.2 & 113.4 & 37.8 & 258.0 & 545.5 & 3672.5 & 898.1 & 248.8 \\
\hline
\end{tabular}




\section{Discussion}

327 The ability of human society to feed the ever-growing population is a major ongoing concern, 328 particularly as climate change is already negatively impacting food production from both 329 terrestrial and marine environments (Brander et al., 2017; Campbell et al., 2017; UNEP, 330 2010). Mollusc aquaculture is increasingly recognised as a solution to this issue. Here, following exposure to temperature and $p \mathrm{CO}_{2}$ levels predicted for 2050 to 2100 , we show species-specific variations in the nutritional quality of two commercially important oyster species. Both O. edulis and M. gigas displayed changes in biochemical (proximate and mineral) composition; in particular M. gigas had lower lipid, carbohydrate, and protein levels, but higher copper concentration, which could pose concerns for both future food safety and security.

\subsection{Condition Index and Moisture content}

339 Condition indices are widely used in aquaculture to evaluate the overall health and value of

340 bivalves, and select specimens of the highest quality (Knights, 2012; Orban et al., 2006;

341 Orban et al., 2002). These indices are correlated with the meat yield, which declines in bivalves under stressful environmental conditions the require significant energetic 343 expenditure (Orban et al., 2002). The condition indexof M. gigas was negatively impacted by

344 elevated temperature but not elevated $p \mathrm{CO}_{2}$, whereas the condition indexof O. edulis was unaffected by any of the treatment conditions, suggesting that the two species did not experience or respond to environmental change in the same way. Changes in condition index

347 reflect the respective changes in feeding and respiration rates to ocean acidification and 348 warming of the two species, as observed by Lemasson et al. (2018). In the Lemasson et al. 349 (2018) study, M. gigas increased its metabolic rate at elevated temperatures and reduced its 
350 feeding rate at elevated levels of $p \mathrm{CO}_{2}(\sim 750 \mathrm{ppm})$, leading to reduced condition index,

351 whereas the metabolic rate and feeding rate of O.edulis was unaffected by ocean

352 acidification and warming. These results are in contrast to those of Lannig et al., (2010) on $M$.

353 gigas who recorded a decrease of $\sim 20 \%$ in condition index between individuals exposed to

354 ambient and elevated $p \mathrm{CO}_{2}$ (see further discussion on the effects of ocean acidification and

355 warming on bivalves in Lemasson et al., 2018). In bivalves, declines in condition index

356 usually suggest depletion of reserves following energetic reallocation, which can lead to

357 changes in individuals biochemical composition (proximate and mineral) and consequently in

358 their nutritional value (see EFSA NDA Panel, 2014; Tate et al., 2017).

359 Water constitutes the major part of oysters (Asha et al., 2014). This component is linked to

360 juiciness, which is an important sensory trait of oysters and influences their marketability

361 (Cruz-Romero et al., 2004). Sensory traits, such as juiciness, texture, appearance, odour or taste, are linked to biochemical composition, and have recently been shown to be unchanged in oysters under ocean acidification and warming (Lemasson et al., 2017b). As was also observed in Turbo militaris (Ab Lah, 2018), here the moisture content of either M. gigas or O. edulis did not change when exposed to ocean acidification and warming conditions.

\subsection{Energetic reserves}

Protein, lipids, and carbohydrates constitute the main energy storage compounds in bivalves, which all have important functions in physiological processes, for instance gametogenesis and reproduction (Dridi et al., 2007). By influencing oysters physiology and metabolic responses, environmental conditions, such as ocean acidification and warming, can dictate the accumulation and depletion of energetic reserves in bivalves (Clements et al., 2018).. 
375 Carbohydrate, in the form of glycogen, is thought to be the energy reserve present in the

376 highest quantity in bivalves and is used to sustain routine metabolic processes (Anacleto et al.,

377 2014, and references therein). A decline in glycogen content under environmental stress (e.g.

378 hypercapnia, hyposalinity, increased temperature) is common in oysters and can indicate

379 physiological stress (Dickinson et al., 2012). Here, the carbohydrate content of $M$. gigas was

380 reduced under ocean acidification and warming, particularly at $\sim 750 \mathrm{ppm} p \mathrm{CO}_{2}$ and elevated

381 temperature, but was unaffected in $O$. edulis. Carbohydrate content remained high in

382 O. edulis ( $>8.5 \%$ wet weight) compared to $M$. gigas (<5\% wet weight). Native bivalve 383 species have previously been shown to have higher glycogen content than non-native and

384 invasive species, this may be a metabolic adaptive strategy to cope with environmental 385 change (Anacleto et al., 2014), and may account for the lack of response of $O$. edulis to ocean 386 acidification and warming here. Given the importance of carbohydrates for oyster 387 maintenance, condition, and their ability to sustain physiological processes, depletion of 388 carbohydrate reserves in M. gigas might jeopardize organisms survival in the long term, 389 which aligns with results showing reduced condition (Lemasson et al., 2018).

Proteins

392 Proteins supply structural elements and have a crucial role in metabolic reactions. Under sustained stress, bivalves can catabolise proteins to mobilise energy once carbohydrates and

394 lipids have been depleted (Barber \& Blake, 1985). Magallana gigas and O. edulis were both 395 high in protein, but under ocean acidification and warming $M$. gigas displayed important reductions. A similar response was shown in the whelk Dicathais orbita, large declines 397 (>50\%) in protein content under ocean acidification and warming (Tate et al., 2017), but in Mytilus edulis (Clements et al., 2018) and T. militaris (Ab Lah et al., 2018), no reductions in protein were observed suggesting taxon-specific responses. 
401

402

403

404

405

406

407

408

409

410

411

412

413

414

415

416 417 Laing, 1998; Pogoda et al., 2013).

\section{Lipids}

The array of lipids in molluscs, with a low proportion of saturated fatty acids and high proportion of polyunsaturated fatty acids (including $\Omega-3$ ), offer numerous health benefits to people (Sprague et al., 2017). Here, M. gigas contained higher levels of lipids ( $1.4-4.8 \%$ wet weight) compared to O. edulis, in the range reported elsewhere (Cochet et al., 2015; Pogoda et al., 2013; Shpigel et al., 1992). In contrast, O. edulis used in this study were relatively poor in crude lipids $(\sim 0.8-1.6 \%$ wet weight), with values below those reported elsewhere (Pogoda et al., 2013). Ocean acidification and warming scenarios led to a decrease in lipid content in both species, particularly notable at $\sim 750 \mathrm{ppm} p \mathrm{CO}_{2}$. Larger absolute reductions occurred in M. gigas (30\%; wet weight percentage) which possessed a higher baseline lipid content under control conditions, but larger percentage reductions were apparent in O. edulis $(\sim 50 \%$; wet weight percentage). Reductions in total lipid content and differences in fatty acid composition (including decreases in polyunsaturated fatty acids) under ocean acidification and warming have been shown in other molluscs (Ab Lah et al., 2018; Tate et al., 2017; Valles-Regino et al., 2015 but see Clements et al. 2018), with variation attributed to differential deposition and energy use rates between species (Child \&

419 Although carbohydrates (and especially glycogen) are often the preferred source of energy 420 for oysters, species-specific differences may exist (see discussion in Pogoda et al., 2013). It has previously been suggested that $O$. edulis preferentially use lipids whereas $M$. gigas use proteins as their principal energy source for metabolic activity when subjected to food limitation (Child \& Laing, 1998). Here, both oyster species when exposed to ocean

424 acidification and warming appeared to use lipids and carbohydrates as their primary source of 
energetic reserves, but to a lesser extent by $O$. edulis, possibly because they did not have

426

427

428

429

430

431

432

433

434

435

436

437

438

439

440

441

442 Although nutritionists often focus on macronutrients, such as calcium $(\mathrm{Ca})$ and magnesium

$443(\mathrm{Mg})$, which are beneficial for teeth and bones (Lambert et al., 2017), there is an increasing

444 understanding of the dietary benefits of trace minerals (FAO, 2016). For instance, potassium

445 (K)-rich foods are considered particularly healthy; selenium (Se) strengthens the immune

important lipid reserves in the first place. Depletions of energetic reserves were indeed

particularly apparent for M. gigas, with additional reductions in proteins reflected in the reduced condition index and caloric content, especially at intermediate $p \mathrm{CO}_{2}$ level. The differential use of energetic reserves by oysters is therefore likely a consequence of the differential physiological stress endured when exposed to ocean acidification and warming conditions (Lemasson et al., under review).

\subsection{Mineral content}

Seafood quality also varies based on the proportion (total ash) and composition of inorganic minerals. In particular, minerals are an essential component of a healthy diet in humans (EFSA NDA Panel, 2014). Here, the two oyster species displayed similar ash content ( 1.92.6\%), which was unimpacted by ocean acidification and warming. In fact, a modest increase in ash content in $O$. edulis under elevated $p \mathrm{CO}_{2}$ might indicate mineral accumulation within the tissue. Ab Lah et al., (2018) have also found no changes in ash content of T. militaris under ocean warming and acidification.

system and reduces oxidative stress in tissue (Rayman, 2000); and zinc ( $\mathrm{Zn}$ ) and iron (Fe) are critical for stamina and disease resistance (Knez et al., 2017; Solomons \& Schümann, 2017). Moreover, micronutrient deficiencies afflict an enormous proportion of the population. For 
instance, over 2 billion people are diagnosed as iron-deficient, and an estimated 800,000

children die every year from zinc deficiency (FAO, 2016).

451

452 In this study, large differences in the levels of macro and micro-nutrients between M. gigas 453 and $O$. edulis were evident, which is unsurprising as species-specific differences in mineral 454 composition is common in bivalves (Bray et al., 2015). Notably, M. gigas exposed to the current climate conditions were relatively high in $\mathrm{K}$, sodium $(\mathrm{Na}), \mathrm{Mg}, \mathrm{Fe}$, and $\mathrm{Se}$ when compared to O. edulis, which was high in $\mathrm{Zn}$. While the values presented here for macro- and micro-minerals are within the ranges described in other studies on oysters and may not be 458 locally dependent (Se: Cantillo, 1998; Fe: Diaz Rizo et al., 2010; Na, K, Mg, Fe, Se: Orban 459 et al., 2004), concentrations of copper $(\mathrm{Cu})$ and $\mathrm{Zn}$ in this study were significantly higher 460 than those commonly found in literature (Cantillo, 1998). High $\mathrm{Cu}$ and $\mathrm{Zn}$ contents have been described for oysters growing in contaminated locations associated with mining and harbour activities (Diaz Rizo et al., 2010; Frias-Espericueta et al., 2009). Plymouth Sound - the

463 location of oyster collection for this study - has a long history of mining that has led to 464 significant contamination of its waters and substrates (see Knights et al., 2016 and references 465 therein), which could explain the elevated $\mathrm{Cu}$ and $\mathrm{Zn}$ levels obtained here.

467 Here, exposure to ocean acidification and warming conditions led to species-specific changes 468 in the concentration of those minerals, with the mineral composition of $M$. gigas being 469 especially affected. A recent study found increased levels of $\mathrm{Zn}$ in T. militaris exposed to 470 ocean acidification and warming conditions, but without changes in other micro- and macro471 elements concentrations (Ab Lah et al., 2018). Here, the reductions in $\mathrm{Ca}, \mathrm{Fe}$, and $\mathrm{Se}$ content in M. gigas exposed to ocean acidification and warming to levels similar or lower than 473 O. edulis, coupled to the accumulation of $\mathrm{Cu}$, represent a measurable change to its nutritional 
474 value, which could have nutritional and safety implications. Copper, along with other trace 475 metals such as arsenic, copper and lead, can become toxic to marine organisms in high

476

477

478

479

480

481

482

483

484

485

486

487

488

489

490

491

492

493

494

495

496

497

498

concentrations (Götze et al., 2014; Moreira et al., 2016), and threaten human health through

seafood ingestion (Bhupander et al., 2011; Han et al., 1998). Since bivalves are filter feeders, they readily accumulate metals present in the surrounding waters into their edible tissue (Lu et al., 2017; Raposo et al., 2009). This process can be modulated by ocean acidification, for instance enhancing the bioaccumulation of $\mathrm{Cu}$ in oysters (Belivermiş et al., 2015; Götze et al., 2014; Hawkins \& Sokolova, 2017; Ivanina et al., 2015; Ivanina et al., 2016). While Cu accumulation under ocean acidification and warming can come at metabolic costs to organisms (Hawkins \& Sokolova, 2017), the implications for human consumption are still unclear. For instance, in Plymouth Sound where background levels are already high, further bioaccumulation of potentially harmful minerals, such as $\mathrm{Cu}$ or $\mathrm{Zn}$, in $M$. gigas could exceed safe levels for consumption.

4.4 Implications for food security and aquaculture management

Our results suggest that the nutritional quality of $M$. gigas, but not $O$. edulis, is likely to be affected by short-termwarming and acidification of coastal seawater caused by $\mathrm{CO}_{2}$ emissions. These changes include reduced proteins, lipids, energetic value, as well as changes to their essential mineral contents. Oysters are seldom a major contributor to human diet, however islands and countries with little agricultural land rely on wild-caught seafood and aquaculture for protein (Cooley et al., 2012). Should the changes observed in oysters be widespread in seafood species, then the nutritional benefits of seafood to human health and its role in food security may be further compromised (Cooley et al., 2012; Ding et al., 2017). Given the need for additional and sustainable sources of proteins, the current exponential 
expansion of the aquaculture industry is inevitable; nevertheless a careful evaluation of this industry as well as the development of appropriate mitigations plans (Clements and Chopin,

501 2017) are needed to ensure that aquaculture is a wise investment in the face of ocean

502 acidification and warming. Diversifying the target species and promoting those currently

503 under-utilized may supplement the industry with 'novel' sources of protein. However, this in

504 practicality might face new challenges, such as selecting species that also thrive under aquaculture conditions and avoiding selecting non-native species (Arismendi et al., 2009), and might require strategic management plants. In order to optimise protein supply and secure socio-economic benefits of mollusc aquaculture, research needs to focus on 508 identifying and selecting native aquaculture species that are resilient to future climate 509 conditions, and able to retain their beneficial nutritional properties (Cooley et al., 2012; Sato et al., 2018), without introducing new challenges.

512 Our results suggest M. gigas is at higher risk of reduction in nutritional quality than its native

513 counterpart $O$. edulis under future ocean acidification and warming scenarios. In the UK, a

514 reduction in the nutritional quality of oysters may not quickly be recognised by consumers,

515 but lower energetic reserves and condition of M. gigas may hold an economic relevance to

516 the aquaculture industry, since this species currently represents $>90 \%$ of the production

517 (Humphreys et al., 2014). Additionally, the biochemical composition can dictate meat

518 appearance, aroma, taste and texture (Cochet et al., 2015; Fratini et al., 2013), and any

519 changes in biochemical composition occurring because of ocean acidification and warming can impact on the sensory quality (Lemasson et al., 2017b). Therefore changes in biochemical composition under ocean acidification and warming can influence the consumer appeal for the product, reducing the demand for it and depressing its economic value (Cooley et al., 2012). As such, the UK aquaculture industry might need to reconsider the management 
524 strategy for the future (Fernandes et al., 2017; Jennings et al., 2016) and consider a shift in

525 focus toward species more robust to climate change, such as $O$. edulis, in order to secure

526 future food provision and economic revenue.

527

5285 Acknowledgements

529 We wish to thank Liz Preston, Victoria Cammack, and Natalie Sweet, technical staff in the 530 Food and Nutrition Unit at Plymouth University, for their help and assistance towards the 531 proximate composition analysis and calorimetry procedures. We also are grateful to Dr 532 Robert Clough and Dr Andy Fisher for their guidance in using the ICP-OES and ICP-MS 533 equipment. Additionally, we are indebted to the following undergraduate students for their 534 continued assistance throughout this study: Samuel Provstgaard-Morys and Lucy Jupe. 535 Finally, we are grateful to Mr Brian Langley, the National Trust, and the Carew Pole Garden 536 Charitable Trust for granting us access to the collection site.

\section{Funding source}

539 This research is supported by a grant awarded to AMK by the School of Biological and

540 Marine Science, Plymouth University, as part of the PhD research of AJL. 
Ab Lah, R., Kelaher, B. P., Bucher, D., \& Benkendorff, K. (2018). Ocean warming and acidification affect the nutritional quality of the commercially-harvested turbinid snail Turbo militaris. Marine environmental research. https://doi.org/10.1016/j.marenvres.2018.08.009

Abarca-Gómez, L., Abdeen, Z. A., Hamid, Z. A., Abu-Rmeileh, N. M., Acosta-Cazares, B., Acuin, C., Adams, R. J., Aekplakorn, W., Afsana, K. \& Aguilar-Salinas, C. A. (2017) 'Worldwide trends in body-mass index, underweight, overweight, and obesity from 1975 to 2016: a pooled analysis of 2416 population-based measurement studies in 128.9 million children, adolescents, and adults'. The Lancet, 390 (10113). pp 2627-2642.

Anacleto, P., Maulvault, A. L., Bandarra, N. M., Repolho, T., Nunes, M. L., Rosa, R. \& Marques, A. (2014) 'Effect of warming on protein, glycogen and fatty acid content of native and invasive clams'. Food Research International, 64 pp 439-445.

AOAC (1995) Official Methods of Analysis of the Association of Official Analytical Chemistry.

Arismendi, I., Soto, D., Penaluna, B., Jara, C., Leal, C., \& León - Muñoz, J. O. R. G. E. (2009). Aquaculture, non - native salmonid invasions and associated declines of native fishes in Northern Patagonian lakes. Freshwater Biology, 54(5), 1135-1147 oyster Crassostrea madrasensis and its nutritional attributes'. The Egyptian Journal of Aquatic Research, 40 (1). pp 35-41.

Barber, B. J. \& Blake, N. J. (1985) 'Intra-organ biochemical transformations associated with oogenesis in the bay scallop, Argopecten irradians concentricus (Say), as indicated by $14 \mathrm{C}$ incorporation'. The Biological Bulletin, 168 (1). pp 39-49.

Barton, A., Waldbusser, G., Feely, R., Weisberg, S., Newton, J., Hales, B., Cudd, S., Eudeline, B., Langdon, C., Jefferds, I., King, T., Suhrbier, A. \& McLauglin, K. (2015) 'Impacts of coastal acidification on the Pacific Northwest shellfish industry and adaptation strategies implemented in response'. Oceanography, 25 (2). pp 146-159.

Belivermiş, M., Warnau, M., Metian, M., Oberhänsli, F., Teyssié, J.-L. \& Lacoue-Labarthe, T. (2015) 'Limited effects of increased $\mathrm{CO}_{2}$ and temperature on metal and radionuclide bioaccumulation in a sessile invertebrate, the oyster Crassostrea gigas'. ICES Journal of Marine Science acidification on marine seafood'. Trends in Ecology and Evolution, 28 (3). pp 178-186.

Brander, K., Cochrane, K., Barange, M. \& Soto, D. (2017) 'Chapter 3. Climate Change Implications for Fisheries and Aquaculture'. Climate Change Impacts on Fisheries and Aquaculture: A Global Analysis. pp 45.

578 Bray, D. J., Green, I., Golicher, D. \& Herbert, R. J. H. (2015) 'Spatial variation of trace metals 579 within intertidal beds of native mussels (Mytilus edulis) and non-native Pacific oysters

580 (Crassostrea gigas): implications for the food web?'. Hydrobiologia, 757 (1). pp 235-249. 
Campbell, B. M., Beare, D. J., Bennett, E. M., Hall-Spencer, J. M., Ingram, J. S. I., Jaramillo, F., Ortiz, R., Ramankutty, N., Sayer, J. A. \& Shindell, D. (2017) 'Agriculture production as a major driver of the Earth system exceeding planetary boundaries'. Ecology and Society, 22 (4).

588 Cantillo, A. Y. (1998) 'Comparison of results of Mussel Watch Programs of the United States 589 and France with Worldwide Mussel Watch Studies'. Marine Pollution Bulletin, 36 (9). pp 712590717.

Child, A. R. \& Laing, I. (1998) 'Comparative low temperature tolerance of small juvenile European, Ostrea edulis L., and Pacific oysters, Crassostrea gigas Thunberg'. Aquaculture Research, 29 (2). pp 103-113.

594 Clements, J. C., \& Chopin, T. (2017). Ocean acidification and marine aquaculture in North America: potential impacts and mitigation strategies. Reviews in Aquaculture, 9(4), 326-341.

596

597

598

599

600

601

602

603

604

605

606

607

608

609

610

611

612

613

614

615

616

617

618

619

620

621

622

623

624

625

626

Clements, J. C., Hicks, C., Tremblay, R., \& Comeau, L. A. (2018). Elevated seawater temperature, not $\mathrm{p} \mathrm{CO} 2$, negatively affects post-spawning adult mussels (Mytilus edulis) under food limitation. Conservation physiology, 6(1), cox078.

Cochet, M., Brown, M., Kube, P., Elliott, N. \& Delahunty, C. (2015) 'Understanding the impact of growing conditions on oysters: a study of their sensory and biochemical characteristics'. Aquaculture Research, 46 (3). pp 637-646.

Cooley, S. R., Cheney, J. E., Kelly, R. P., \& Allison, E. H. (2017). 2 Ocean acidification and Pacific oyster larval failures in the Pacific Northwest United States'. Global Change in Marine Systems: Societal and Governing Responses.

Cooley, S. R., Lucey, N., Kite-Powell, H. \& Doney, S. C. (2012) 'Nutrition and income from molluscs today imply vulnerability to ocean acidification tomorrow'. Fish and Fisheries, 13 (2). pp 182-215.

Cooley, S. R., Rheuban, J. E., Hart, D. R., Luu, V., Glover, D. M., Hare, J. A. \& Doney, S. C. (2015) 'An integrated assessment model for helping the United States sea scallop (Placopecten magellanicus) fishery plan ahead for ocean acidification and warming'. PLoS One, 10 (5). pp e0124145.

Cruz-Romero, M., Smiddy, M., Hill, C., Kerry, J. \& Kelly, A. (2004) 'Effects of high pressure treatment on physicochemical characteristics of fresh oysters (Crassostrea gigas)'. Innovative Food Science \& Emerging Technologies., 5 (2). pp 161-169.

Delgado, C. L. (2003) Fish to 2020: Supply and demand in changing global markets. vol. 62. Penang, Malaysia: WorldFish, 2003.

Diaz Rizo, O., Olivares Reumont, S., Viguri Fuente, J., Diaz Arado, O., Lopez Pino, N., D'Alessandro Rodriguez, K., de la Rosa Medero, D., Gelen Rudnikas, A. \& Arencibia Carballo, G. (2010) 'Copper, zinc and lead enrichments in sediments from Guacanayabo Gulf, Cuba, and its bioaccumulation in oysters, Crassostrea rhizophorae'. Bulletin of Environmental Contamination and Toxicology, 84 (1). pp 136-140.

Dickinson, G. H., Ivanina, A. V., Matoo, O. B., Portner, H. O., Lannig, G., Bock, C., Beniash, E. \& Sokolova, I. M. (2012) 'Interactive effects of salinity and elevated $\mathrm{CO}_{2}$ levels on juvenile eastern oysters, Crassostrea virginica'. J Exp Biol, 215 (Pt 1). pp 29-43.

Ding, Q., Chen, X., Hilborn, R. \& Chen, Y. (2017) 'Vulnerability to impacts of climate change on marine fisheries and food security'. Marine Policy, 83 pp 55-61. 
Dridi, S., Romdhane, M. S. \& Elcafsi, M. h. (2007) 'Seasonal variation in weight and biochemical composition of the Pacific oyster, Crassostrea gigas in relation to the gametogenic cycle and environmental conditions of the Bizert lagoon, Tunisia'. Aquaculture, 263 (1-4). pp 238-248.

Dupont, S., Hall, E., Calosi, P. \& Lundve, B. (2014) 'First evidence of altered sensory quality in a shellfish exposed to decreased $\mathrm{pH}$ relevant to ocean acidification'. Journal of Shellfish Research, 33 (3). pp 857-861.

EFSA NDA Panel (2014) 'Scientific Opinion on health benefits of seafood (fish and shellfish) consumption in relation to health risks associated with exposure to methylmercury'. EFSA Journal, 12 (7). pp 3761.

Ekstrom, J. A., Suatoni, L., Cooley, S. R., Pendleton, L. H., Waldbusser, G. G., Cinner, J. E., Ritter, J., Langdon, C., van Hooidonk, R., Gledhill, D., Wellman, K., Beck, M. W., Brander, L. M., Rittschof, D., Doherty, C., Edwards, P. E. T. \& Portela, R. (2015) 'Vulnerability and

640 adaptation of US shellfisheries to ocean acidification'. Nature Climate Change, 5 (3). pp 207214.

642 FAO (2014) 'The State of World Fisheries and Aquaculture 2014. Rome. 223 pp.'.

FAO (2016) The State of World Fisheries and Aquaculture 2016. Contributing to food 644 security and nutrition for all. Rome. 200 pp. Available.

FAO/WHO (2011) Report of the Joint FAO/WHO Expert Consultation on the Risks and Benefits of Fish Consumption. Rome, Food and Agriculture Organization of the United Nations; Geneva, World Health Organization, 50pp. Available.

648 Fernandes, J. A., Papathanasopoulou, E., Hattam, C., Queirós, A. M., Cheung, W. W. W. L., 649 Yool, A., Artioli, Y., Pope, E. C., Flynn, K. J., Merino, G., Calosi, P., Beaumont, N., Austen, M. C., Widdicombe, S. \& Barange, M. (2017) 'Estimating the ecological, economic and social impacts of ocean acidification and warming on UK fisheries'. Fish and Fisheries, 18 (3). pp 389-411.

Fernandez, A., Grienke, U., Soler-Vila, A., Guiheneuf, F., Stengel, D. B. \& Tasdemir, D. (2015) 'Seasonal and geographical variations in the biochemical composition of the blue mussel (Mytilus edulis L.) from Ireland'. Food Chemistry, 177 pp 43-52.

Firth, L. B., Knights, A. M., Thompson, R., Mieszkowska, N., Bridger, D., Evans, A., Moore, P., O'Connor, N., Sheehan, E. \& Hawkins, S. J. (2016) 'Ocean sprawl: challenges and opportunities for biodiversity management in a changing world'. Oceanography and Marine Biology: An Annual Review

660 Fratini, G., Medina, I., Lupi, P., Messini, A., Pazos, M. \& Parisi, G. (2013) 'Effect of a 661 finishing period in sea on the shelf life of Pacific oysters (C. gigas) farmed in lagoon'. Food 662 Res Int, 51 (1). pp 217-227.

663 Frias-Espericueta, M. G., Osuna-Lopez, I., Banuelos-Vargas, I., Lopez-Lopez, G., Muy664 Rangel, M. D., Izaguirre-Fierro, G., Rubio-Carrasco, W., Meza-Guerrero, P. C. \& Voltolina, D. 665 (2009) 'Cadmium, copper, lead and zinc contents of the mangrove oyster, Crassostrea Contamination and Toxicology., 83 (4). pp 595-599.

668 Froehlich, H. E., Runge, C. A., Gentry, R. R., Gaines, S. D., \& Halpern, B. S. (2018). 669 Comparative terrestrial feed and land use of an aquaculture-dominant world. Proceedings of 670 the National Academy of Sciences, 201801692. 
671 Gentry, R. R., Froehlich, H. E., Grimm, D., Kareiva, P., Parke, M., Rust, M., Gaines, S.D. \&

672 Halpern, B. S. (2017). Mapping the global potential for marine aquaculture. Nature ecology \&

673 evolution, 1(9), 1317.

674 Gerland, P., Raftery, A. E., Ševčíková, H., Li, N., Gu, D., Spoorenberg, T., Alkema, L.,

675 Fosdick, B. K., Chunn, J. \& Lalic, N. (2014) 'World population stabilization unlikely this

676 century'. Science, 346 (6206). pp 234-237.

677 Golam, K., Haroon Yousuf, A. K., \& Dayanthi, N. (2017). Climate change impacts on tropical

678 and temperate fisheries, aquaculture, and seafood security and implications-A review.

679 Livestock Research for Rural Development, 29.

680 Götze, S., Matoo, O. B., Beniash, E., Saborowski, R. \& Sokolova, I. M. (2014) 'Interactive

681 effects of $\mathrm{CO} 2$ and trace metals on the proteasome activity and cellular stress response of

682 marine bivalves Crassostrea virginica and Mercenaria mercenaria'. Aquatic Toxicology, 149

683 pp 65-82.

684 Han, B. C., Jeng, W. L., Chen, R. Y., Fang, G. T., Hung, T. C., \& Tseng, R. J. (1998).

685 Estimation of target hazard quotients and potential health risks for metals by consumption of

686 seafood in Taiwan. Archives of environmental contamination and toxicology, 35(4), 711-720.

687 Hart, F. L. \& Fisher, H. J. (1971) 'Introduction-General methods for proximate and mineral

688 analysis'. Modern Food Analysis. Berlin, Heidelberg: Springer Berlin Heidelberg, pp 1-27.

689 Hawkins, C. A. \& Sokolova, I. M. (2017) 'Effects of elevated $\mathrm{CO}_{2}$ levels on subcellular

690 distribution of trace metals ( $\mathrm{Cd}$ and $\mathrm{Cu}$ ) in marine bivalves'. Aquatic Toxicology, 192

691 (Supplement C). pp 251-264.

692 Hilborn, R., J. Banobi, S. J. Hall, T. Pucylowski, and T. E. Walsworth. (2018). The

693 environmental costs of animal source foods. Frontiers in Ecology and the Environment doi:

694 10.1002/fee.1822.

695 Humphreys, J., Herbert, R. J. H., Roberts, C. \& Fletcher, S. (2014) 'A reappraisal of the

696 history and economics of the Pacific oyster in Britain'. Aquaculture, 428-429 pp 117-124.

697 Hurlbert, S. H. (1984) 'Pseudoreplication and the Design of Ecological Field Experiments'.

698 Ecological Monograph, 54 (2). pp 187-211.

699 IPCC (2013): Summary for Policymakers. In: Climate Change 2013: The Physical Science

700 Basis. Contribution of Working Group I to the Fifth Assessment Report of the

701 Intergovernmental Panel on Climate Change [Stocker, T.F., D. Qin, G.-K. Plattner, M. Tignor,

702 S.K. Allen, J. Boschung, A. Nauels, Y. Xia, V. Bex and P.M. Midgley (eds.)]. Cambridge

703 University Press, Cambridge, United Kingdom and New York, NY, USA.

704 Ivanina, A. V., Hawkins, C., Beniash, E. \& Sokolova, I. M. (2015) 'Effects of environmental

705 hypercapnia and metal ( $\mathrm{Cd}$ and $\mathrm{Cu}$ ) exposure on acid-base and metal homeostasis of

706 marine bivalves'. Comparative Biochemistry and Physiology Part C: Toxicology \&

707 Pharmacology,

708 Ivanina, A. V., Hawkins, C. \& Sokolova, I. M. (2016) 'Interactive effects of copper exposure

709 and environmental hypercapnia on immune functions of marine bivalves Crassostrea

710 virginica and Mercenaria mercenaria'. Fish and Shellfish Immunology, 49 pp 54-65.

711 Jennings, S., Stentiford, G. D., Leocadio, A. M., Jeffery, K. R., Metcalfe, J. D., Katsiadaki, I.,

712 Auchterlonie, N. A., Mangi, S. C., Pinnegar, J. K., Ellis, T., Peeler, E. J., Luisetti, T., Baker-

713 Austin, C., Brown, M., Catchpole, T. L., Clyne, F. J., Dye, S. R., Edmonds, N. J., Hyder, K.,

714 Lee, J., Lees, D. N., Morgan, O. C., O'Brien, C. M., Oidtmann, B., Posen, P. E., Santos, A. 
715 R., Taylor, N. G. H., Turner, A. D., Townhill, B. L. \& Verner-Jeffreys, D. W. (2016) 'Aquatic

716 food security: insights into challenges and solutions from an analysis of interactions between

717 fisheries, aquaculture, food safety, human health, fish and human welfare, economy and

718 environment'. Fish and Fisheries, 17 (4). pp 893-938.

719 Kjeldahl, J. (1883) 'Neue Methode zur Bestimmung des Stickstoffs in organischen Körpern'.

720 Zeitschrift für analytische Chemie, 22 (1). pp 366-383.

721 Knez, M., Nikolic, M., Zekovic, M., Stangoulis, J. C. R., Gurinovic, M. \& Glibetic, M. (2017)

722 'The influence of food consumption and socio-economic factors on the relationship between

723 zinc and iron intake and status in a healthy population'. Public Health Nutrition, 20 (14). pp

724 2486-2498.

Knights, A. M. (2012) 'Spatial variation in body size and reproductive condition of subtidal mussels: Considerations for sustainable management'. Fisheries Research, 113 (1). pp 4554.

Knights, A. M., Firth, L. B., Thompson, R. C., Yunnie, A. L. E., Hiscock, K. \& Hawkins, S. J. (2016) 'Plymouth - A World Harbour through the ages'. Regional Studies in Marine Science,

7308 (Part 2). pp 297-307.

731

732

733

734

735

736

737

738

739

740

741

742

743

744

745

746

747

748

749

750

751

752

753

754

755

756

757

Knights, A. M., Piet, G. J., Jongbloed, R. H., Tamis, J. E., White, L., Akoglu, E., Boicenco, L., Churilova, T., Kryvenko, O. \& Fleming-Lehtinen, V. (2015) 'An exposure-effect approach for evaluating ecosystem-wide risks from human activities'. ICES Journal of Marine Science: Journal du Conseil, 72 (3). pp 1105-1115.

Lambert, H., Hakim, O. \& Lanham-New, S. A. (2017) 'Chapter 8: Major minerals: calcium and magnesium'. Essentials of Human Nutrition. pp 131.

Lannig, G., Eilers, S., Pörtner, H.O., Sokolova, I.M. and Bock, C. (2010). Impact of ocean acidification on energy metabolism of oyster, Crassostrea gigas-changes in metabolic pathways and thermal response. Marine drugs, 8(8), pp.2318-2339.

Lemasson, A. J., Fletcher, S., Hall-Spencer, J. M. \& Knights, A. M. (2017a) 'Linking the biological impacts of ocean acidification on oysters to changes in ecosystem services: $A$ review'. Joiurnal of Experimental Marine Biology and Ecology, 492 pp 49-62.

Lemasson, A. J., Hall-Spencer, J. M., Fletcher, S., Provstgaard-Morys, S., \& Knights, A. M. (2018). Indications of future performance of native and non-native adult oysters under acidification and warming. Marine Environmental Research.

https://doi.org/10.1016/j.marenvres.2018.10.003

Lemasson, A. J., Kuri, V., Hall-Spencer, J. M., S., F., Moate, R. \& Knights, A. M. (2017b)

'Sensory qualities of oysters unaltered by a short exposure to combined elevated $p \mathrm{CO}_{2}$ and temperature'. Frontiers in Marine Science, 4 (352).

Lloret, J., Rätz, H.-J., Lleonart, J. \& Demestre, M. (2016) 'Challenging the links between seafood and human health in the context of global change'. Journal of the Marine Biological Association of the UK, 96 (01). pp 29-42.

Lu, G. Y., Ke, C. H., Zhu, A. \& Wang, W. X. (2017) 'Oyster-based national mapping of trace metals pollution in the Chinese coastal waters'. Environmental Pollution, 224 pp 658-669.

Lucas, A. \& Beninger, P. G. (1985) 'The use of physiological condition indices in marine bivalve aquaculture'. Aquaculture, 44 (3). pp 187-200. 
Luque de Castro, M. D. \& García-Ayuso, L. E. (1998) 'Soxhlet extraction of solid materials: an outdated technique with a promising innovative future'. Analytica Chimica Acta, 369 (1-2). pp 1-10.

761

762

763

764

765

766

767

768

769

770

771

772

773

774

775

776

777

778

779

780

781

782

783

784

785

786

787

788

789

790

791

792

793

794

795

796

797

798

799

Maclean, W., Harnly, J., Chen, J., Chevassus-Agnes, S., Gilani, G., Livesey, G. \& Warwick, P. (2003) 'Food energy-Methods of analysis and conversion factors', Food and Agriculture Organization of the United Nations Technical Workshop Report.

Macura, B., Lönnstedt, O. M., Byström, P., Airoldi, L., Eriksson, B. K., Rudstam, L. \& Støttrup, J. (2016) 'What is the impact on fish recruitment of anthropogenic physical and structural habitat change in shallow nearshore areas in temperate systems? A systematic review protocol'. Environmental Evidence, 5 (1). pp 1-8.

Manirakiza, P., Covaci, A. \& Schepens, P. (2001) 'Comparative Study on Total Lipid Determination using Soxhlet, Roese-Gottlieb, Bligh \& Dyer, and Modified Bligh \& Dyer Extraction Methods'. Journal of Food Composition and Analysis, 14 (1). pp 93-100.

Marin, M. G., Moschino, V., Deppieri, M. \& Lucchetta, L. (2003) 'Variations in gross biochemical composition, energy value and condition index of $T$. philippinarum from the Lagoon of Venice'. Aquaculture, 219 (1-4). pp 859-871.

McCauley, D. J., Pinsky, M. L., Palumbi, S. R., Estes, J. A., Joyce, F. H. \& Warner, R. R. (2015) 'Marine defaunation: animal loss in the global ocean'. Science, 347 (6219). pp 1255641.

Moreira, A., Figueira, E., Soares, A. M., \& Freitas, R. (2016). The effects of arsenic and seawater acidification on antioxidant and biomineralization responses in two closely related Crassostrea species. Science of the Total Environment, 545, 569-581.

Naylor, R. L., Goldburg, R. J., Primavera, J. H., Kautsky, N., Beveridge, M. C., Clay, J., Folke, C., Lubchenco, J., Mooney, H. \& Troell, M. (2000) 'Effect of aquaculture on world fish supplies'. Nature, 405 (6790). pp 1017-1024.

Nielsen, S. S. (2006) 'Proximate Assays in Food Analysis'. Encyclopedia of Analytical Chemistry. John Wiley \& Sons, Ltd.

Orban, E., Di Lena, G., Masci, M., Nevigato, T., Casini, I., Caproni, R., Gambelli, L. \& Pellizzato, M. (2004) 'Growth, nutritional quality and safety of oysters (Crassostrea gigas) cultured in the lagoon of Venice (Italy)'. Journal of the Science of Food and Agriculture, 84 (14). pp 1929-1938.

Orban, E., Di Lena, G., Nevigato, T., Casini, I., Caproni, R., Santaroni, G. \& Giulini, G. (2006) 'Nutritional and commercial quality of the striped venus clam, Chamelea gallina, from the Adriatic sea'. Food Chemistry, 101 (3). pp 1063-1070.

Orban, E., Di Lena, G., Nevigato, T., Casini, I., Marzetti, A. \& Caproni, R. (2002) 'Seasonal changes in meat content, condition index and chemical composition of mussels (Mytilus galloprovincialis) cultured in two different Italian sites'. Food Chemistry, 77 pp 57-65.

Pauly, D., Christensen, V., Dalsgaard, J., Froese, R. \& Torres, F. (1998) 'Fishing down marine food webs'. Science, 279 (5352). pp 860-863.

Pinnegar, J. K., Buckley, P. \& Engelhard, G. H. (2017) 'Chapter 12. Impacts of Climate Change in the United Kingdom and Ireland'. Climate Change Impacts on Fisheries and Aquaculture: A Global Analysis. pp 381. 
800 Pogoda, B., Buck, B. H., Saborowski, R. \& Hagen, W. (2013) 'Biochemical and elemental

801 composition of the offshore-cultivated oysters Ostrea edulis and Crassostrea gigas'.

802 Aquaculture, 400-401 pp 53-60.

803 Porter, J. R., Xie, L., Challinor, A. J., Cochrane, K., Howden, S. M., Iqbal, M. M., Lobell, D. B.

804 \& Travasso, M. I. (2014) 'Food security and food production systems'. Climate Change 2014:

805 Impacts, Adaptation, and Vulnerability. Part A: Global and Sectoral Aspects. Contribution of

806 Working Group II to the Fifth Assessment Report of the Intergovernmental Panel on Climate

807 Change. Cambridge University Press, Cambridge, United Kingdom and New York, NY, USA,

808 pp pp. $485-533$.

809 Raposo, J. C., Bartolome, L., Cortazar, E., Arana, G., Zabaljauregui, M., de Diego, A.,

810 Zuloaga, O., Madariaga, J. M. \& Etxebarria, N. (2009) 'Trace metals in oysters, Crassotrea

811 sps., from UNESCO protected natural reserve of Urdaibai: space-time observations and

812 source identification'. Bulletin of Environmental Contamination and Toxicology, 83 (2). pp

813 223-229.

814 Rayman, M. P. (2000) 'The importance of selenium to human health'. The Lancet, 356

815 (9225). pp 233-241.

816 Rider, S. A., Davies, S. J., Jha, A. N., Clough, R. \& Sweetman, J. W. (2010). Bioavailability 817 of co-supplemented organic and inorganic zinc and selenium sources in a white fishmeal-

818 based rainbow trout (Oncorhynchus mykiss) diet. Journal of Animal Physiology and Animal

819 Nutrition, 94 (1), pp. 99-110.

820 Rice, J. C., and Garcia, S. M. (2011). Fisheries, food security, climate change, and

821 biodiversity: characteristics of the sector and perspectives on emerging issues. - ICES

822 Journal of Marine Science, 68: 1343-1353.

823 Rossbach, L. M., Shaw, B. J., Piegza, D., Vevers, W. F., Atfield, A. J. \& Handy, R. D. (2017)

824 Sub-lethal effects of waterborne exposure to copper nanoparticles compared to copper

825 sulphate on the shore crab (Carcinus maenas). Aquatic Toxicology, 191 pp. 245-255.

826 Sato, K.N., Powell, J., Rudie, D., Levin, L.A. and Handling editor: Mary Hunsicker (2018).

827 Evaluating the promise and pitfalls of a potential climate change-tolerant sea urchin fishery

828 in southern California. ICES Journal of Marine Science, 75(3), pp.1029-1041.

829 Shpigel, M., Barber, B. J. \& Mann, R. (1992) 'Effects of elevated temperature on growth,

830

831

832 Simopoulos, A. P. (2002) 'The importance of the ratio of omega-6/omega-3 essential fatty

833 acids'. Biomedicine \& pharmacotherapy, 56 (8). pp 365-379.

834 Solomons, N. W. \& Schümann, K. (2017) 'Iron and Zinc: Two Principal Trace Element

835 Nutrients in the Context of Food Security Transitions'. in Biesalski, H.K., Drewnowski, A.,

836 Dwyer, J.T., Strain, J.J., Weber, P. and Eggersdorfer, M. (eds.) Sustainable Nutrition in a

837 Changing World. Cham: Springer International Publishing, pp 205-222.

838 Soto-Jiménez, M., Páez-Osuna, F. \& Morales-Hernández, F. (2001) 'Selected trace metals

839

840

841 in oysters (Crassostrea iridescens) and sediments from the discharge zone of the submarine sewage outfall in Mazatlán Bay (southeast Gulf of California): chemical fractions and bioaccumulation factors'. Environmental Pollution, 114 (3). pp 357-370.

842 Sprague, M., Betancor, M. B., Dick, J. R. \& Tocher, D. R. (2017) 'Nutritional evaluation of 843 seafood, with respect to long-chain omega-3 fatty acids, available to UK consumers'.

844 Proceedings of the Nutrition Society, 76 (OCE2). 
845 Tacon, A. G. J. \& Metian, M. (2013) 'Fish matters: importance of aquatic foods in human

846 nutrition and global food supply'. Reviews in Fisheries Science, 21 (1). pp 22-38.

847 Tate, R. D., Benkendorff, K., Ab Lah, R. \& Kelaher, B. P. (2017) 'Ocean acidification and

848 warming impacts the nutritional properties of the predatory whelk, Dicathais orbita'. Journal

849 of Experimental Marine Biology and Ecology, 493 pp 7-13.

850 Troell, M., Naylor, R.L., Metian, M., Beveridge, M., Tyedmers, P.H., Folke, C., Arrow, K.J.,

851 Barrett, S., Crépin, A.S., Ehrlich, P.R. and Gren, A., (2014). Does aquaculture add resilience

852 to the global food system?. Proceedings of the National Academy of Sciences, 111(37),

853 pp.13257-13263.

854 UNEP (2010) UNEP Emerging Issues: Environmental Consequences of Ocean Acidification:

855 A Threat to Food Security. UNEP. Available.

856 United Nations, D. o. E. a. S. A., Population Division (2015) 'World Population Prospects:

857 The 2015 Revision, Key Findings and Advance Tables. Working Paper No. ESA/P/WP.241.'.

858 Valles-Regino, R., Tate, R., Kelaher, B., Savins, D., Dowell, A. \& Benkendorff, K. (2015)

859 'Ocean warming and $\mathrm{CO}_{2}$-induced acidification impact the lipid content of a marine predatory

860 gastropod'. Marine Drugs, 13 (10). pp 6019-6037.

861 Weatherdon, L. V., Magnan, A. K., Rogers, A. D., Sumaila, U. R. \& Cheung, W. W. L. (2016)

862 'Observed and projected impacts of climate change on marine fisheries, aquaculture, coastal

863 tourism, and human health: an update'. Frontiers in Marine Science, 3 


\section{Highlights: (3-5)}

866 Ocean acidification and warming can reduce oysters nutritional quality

867 Changes to nutritional composition were more pronounced in the introduced species

868 - Oysters displayed decreased protein, lipid, and carbohydrate contents

869 - Multifaceted implications for the aquaculture sector and future food security 